\title{
An Application of Bioassessment Metrics and Multivariate Techniques to Evaluate Central Nebraska Streams
}

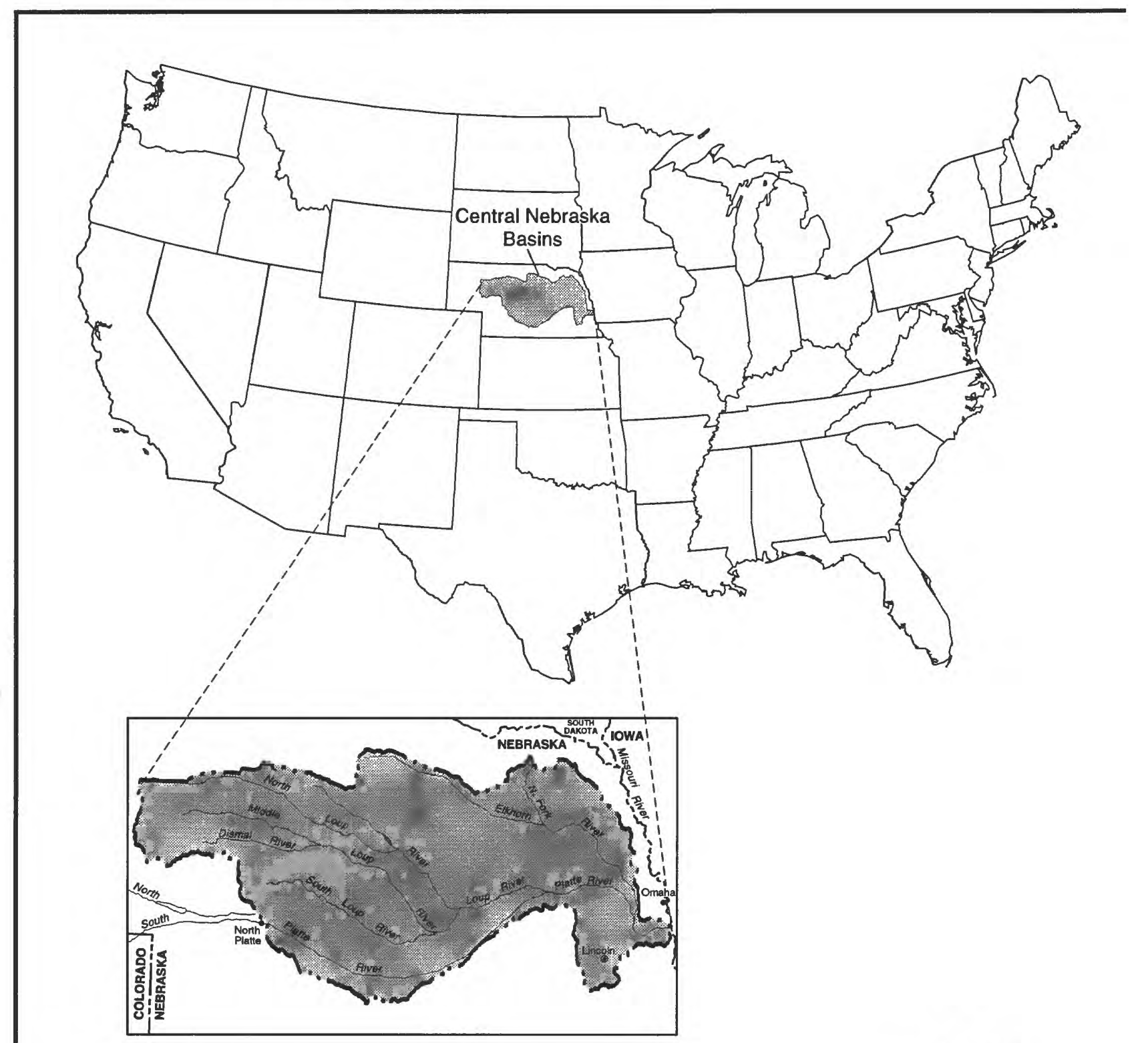

U.S. GEOLOGICAL SURVEY

Water-Resources Investigations Report 96-4152

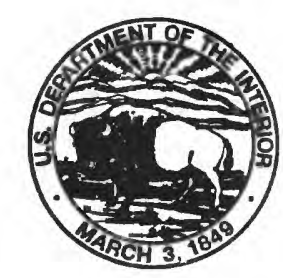

NATIONAL WATER-QUALITY ASSESSMENT PROGRAM 


\section{An Application of Bioassessment Metrics and Multivariate Techniques to Evaluate Central Nebraska Streams}

\section{By STEVEN A. FRENZEL}

U.S. GEOLOGICAL SURVEY

Water-Resources Investigations Report 96-4152

Prepared as part of the

NATIONAL WATER-QUALITY ASSESSMENT

PROGRAM 


\section{U.S. DEPARTMENT OF THE INTERIOR \\ BRUCE BABBITT, Secretary}

U.S. GEOLOGICAL SURVEY

Gordon P. Eaton, Director

The use of firm, trade, and brand names in this report is for identification purposes only and does not constitute endorsement by the U.S. Geological Survey.

For additional information write to:

Copies of this report can be purchased from:

District Chief

U.S. Geological Survey

Room 406, Federal Building

100 Centennial Mall North

Lincoln, NE 68508
U.S. Geological Survey

Branch of Information Services

Box 25286

Denver, CO 80225-0286 


\section{CONTENTS}

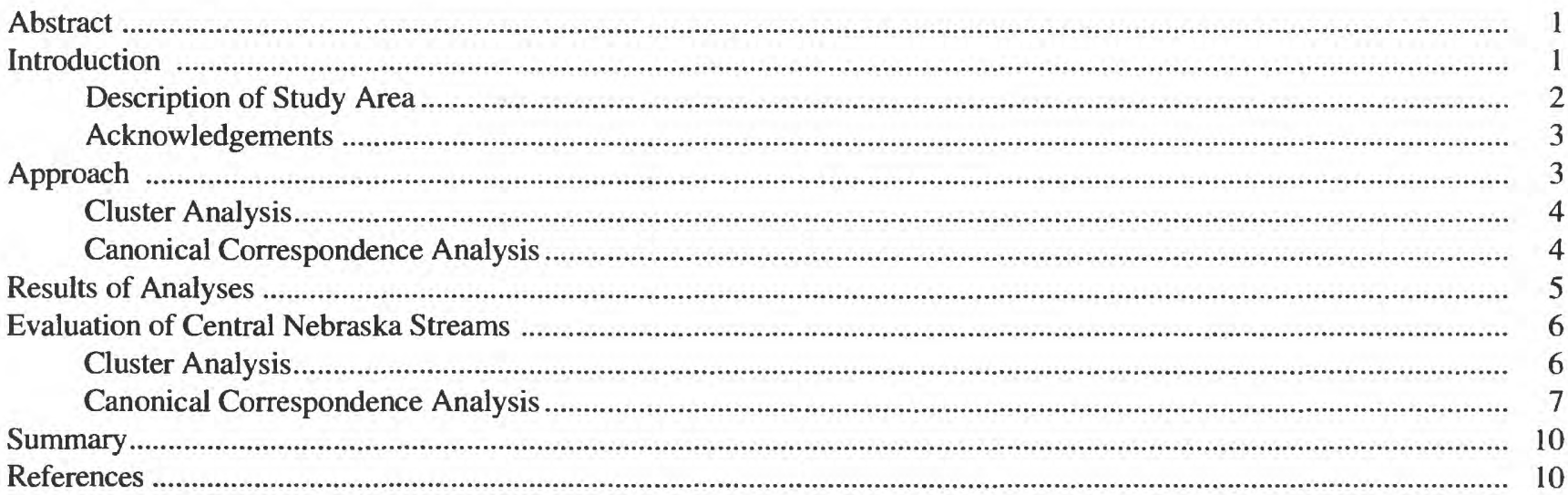

\section{FIGURES}

1. Map showing subunits of Central Nebraska Basins NAWQA study area and site classification into four clusters as determined by TWINSPAN.

2. Graph showing flow-duration curves for streams of similar drainage areas in the four landscape subunits......... 3

3. Graph showing ordination of site locations on the basis of macroinvertebrate community composition and environmental variables

\section{TABLES}

1. Synthetic reference condition used for RBP site assessment

4

2. Contingency table for TWINSPAN clusters and log-likelihood ratio test statistic................................................ 6

3. Results of Wilcoxon rank-sum tests between clusters of stream sites in central Nebraska ................................. 7

4. Ranking of environmental variables from forward selection in canonical correspondence analysis .................... 7

5. Results of canonical correspondence analysis and partial canonical correspondence analysis of significant environmental variables 
IV An Application of Bioassessment Metrics and Multivariate Techniques to Evaluate Central Nebraska Streams 


\title{
An Application of Bioassessment Metrics and Multivariate Techniques to Evaluate Central Nebraska Streams
}

\author{
By Steven A. Frenzel
}

\section{Abstract}

Ninety-one stream sites in central Nebraska were classified into four clusters on the basis of a cluster analysis (TWINSPAN) of macroinvertebrate data. Rapid bioassessment protocol scores for macroinvertebrate species were significantly different among sites grouped by the first division into two clusters. This division may have distinguished sites on the basis of water-quality impairment. Individual metrics that differed between clusters of sites were the Hilsenhoff Biotic Index, the number of Ephemeroptera, Plecoptera, and Trichoptera (EPT) taxa, and the ratio of individuals in EPT to Chironomidae taxa. Canonical correspondence analysis of 57 of the 91 sites showed that stream width, site altitude, latitude, soil permeability, water temperature, and mean annual precipitation were the most important environmental variables describing variance in the species-environment relation. Stream width and soil permeability reflected streamflow characteristics of a site, whereas site altitude and latitude were factors related to general climatic conditions. Mean annual precipitation related to both streamflow and climatic conditions.

\section{INTRODUCTION}

Water quality is an integration of physical, chemical, and biological factors, and its assessment may be of a spatial or temporal nature. To assess the status and trends in water quality and to develop a better under- standing of the natural and human factors that affect water quality, the U.S. Geological Survey has begun a National Water-Quality Assessment (NAWQA) Program.

There is an increasing use of biological attributes, or metrics, to describe water quality. Southerland and Stribling (1995) found that some type of multimetric approach is used in a large majority of water-quality monitoring programs. Biological monitoring has become a valuable supplement to chemical-based monitoring because the biota respond to the cumulative effects to which they are exposed (Dixit and others, 1992; Rosenberg and Resh, 1993).

Two main approaches exist for the evaluation of water quality from biological data-biological metrics and multivariate statistical approaches. Biological metrics attempt to relate measures of an assemblage to an expectation of what those measures would be in a minimally disturbed system (Karr and others, 1986; Plafkin and others, 1989). Biological metrics may be as simple as a single numerical index such as a diversity index or a comparative rating of multiple metrics such as the U.S. Environmental Protection Agency's rapid bioassessment protocols (RBPs) (Plafkin and others, 1989) and the Index of Biotic Integrity (IBI) (Karr, 1981). These approaches are seen as easily understood by nonexperts and allow comparisons where statistical requirements are not satisfied (Norris, 1995).

Multivariate statistical methods also have been used to reveal physical and chemical factors that contribute to the biological attributes observed (Wright and others, 1984; Leland and Carter, 1986; Richards and others, 1993). Indeed, it can be argued that the 
linkage of environmental and biological data is a multivariate problem (Norris and Georges, 1993).

Although both multimetric and multivariate statistical approaches have merit, the potential advantages and disadvantages of these approaches for water-quality assessments of large study areas are unclear. Therefore, the purpose of this report is to present an evaluation of macroinvertebrate data for streams in a large part of central Nebraska using biological metrics and multivariate statistical approaches. The report specifically addresses: (1) whether clusters of sites defined by their macroinvertebrate assemblages correspond with the four landscape subunits described for the study area, (2) which biological metrics were able to differentiate between clusters of these sites, and (3) which environmental variables were best correlated with macroinvertebrate assemblages at these sites.

\section{Description of the Study Area}

The Central Nebraska Basins NAWQA study area consists of the Platte River drainage from North Platte, Nebraska, to its confluence with the Missouri River south of Omaha (fig. 1). The environmental setting within this study area is defined by four landscape subunits-Sandhills, Loess Hills, Glaciated Area, and Platte Valley (Huntzinger and Ellis, 1993). Subunits were determined by differences in physiography, geology, hydrology, and land use. These subunits correspond approximately to the Nebraska ecoregions described by Omernik (1987), although the Platte Valley is not differentiated by Omernik.

Streamflow characteristics are the result of complex environmental conditions. However, streamflow was not monitored at most biological sampling sites prior to the Central Nebraska Basins NAWQA study, and a surrogate measure was sought. Drainage area often is used as a surrogate for streamflow. Inherent in that approach is that all of the drainage area contributes to runoff. This assumption does not hold true for

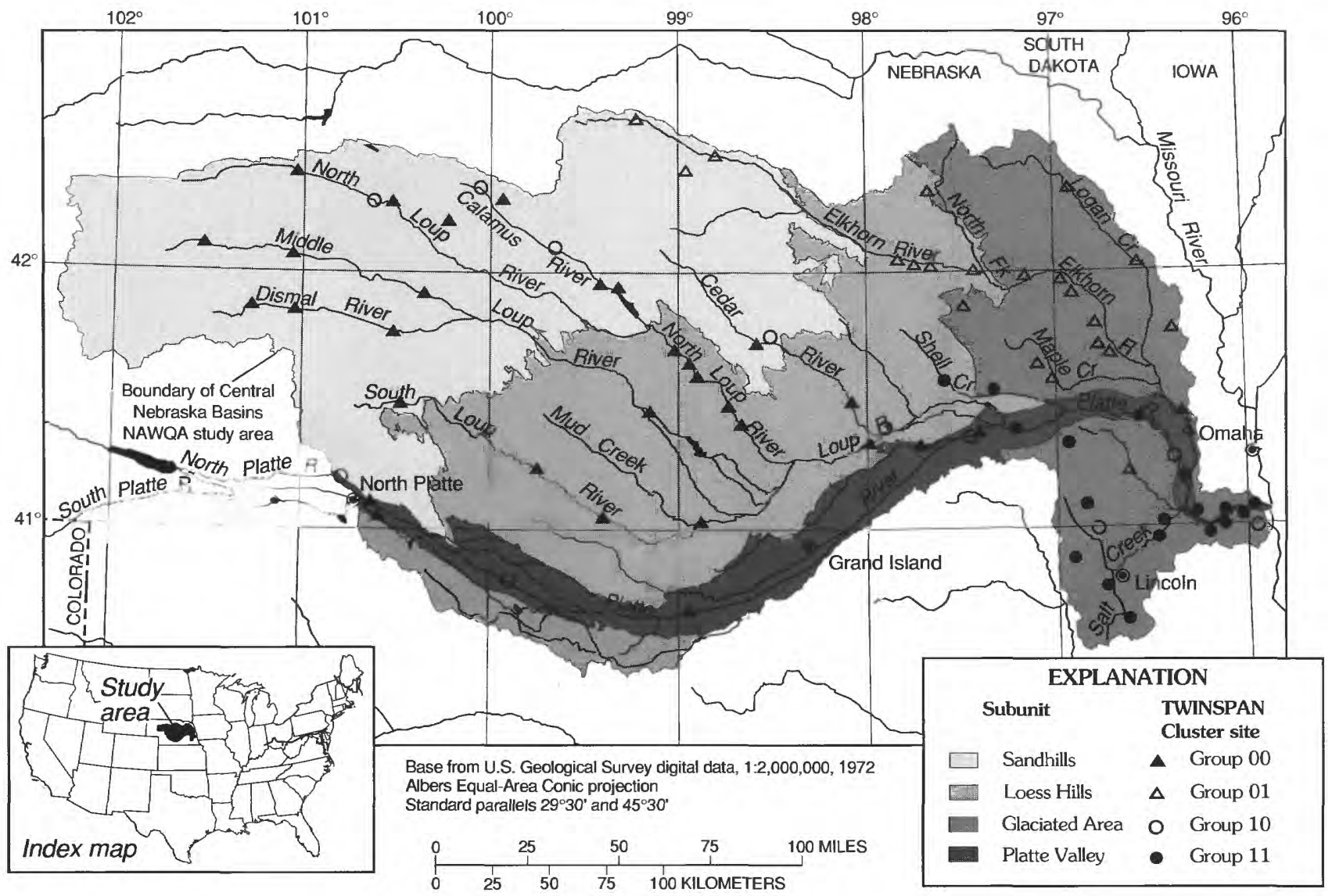

Figure 1. Subunits of Central Nebraska Basins NAWQA study area and site classification into four clusters as determined by TWINSPAN (Hill, 1979) (data from Nebraska Department of Environmental Control, 1991). 
the Sandhills where the extremely permeable soils attenuate storm runoff. Of the variables available, soil permeability probably best corresponds to a descriptor of streamflow variability and predictability. Soils with high permeability are less likely to produce surface runoff than soils with low permeability. Therefore, basins characterized by soils with high permeability generally have stable base flows and reduced peak flows.

In central Nebraska, there is a sharp contrast between soil permeability in the Sandhills and in the other landscape subunits. Figure 2 shows the runoff characteristics from streams of comparable drainage areas in the different subunits. The Calamus River, a typical Sandhills stream, has a relatively flat flowduration curve indicating little change from base flow to peak flow. Flow-duration curves for Mud Creek (Loess Hills) and Logan Creek (Glaciated Area) differ from the Calamus River, showing a greater response to precipitation. Differences in discharge between Mud and Logan Creeks are probably a function of differences in precipitation. Flow characteristics of the Wood River in the Platte Valley subunit are largely affected by irrigation practices.

\section{Acknowledgments}

The author thanks Ken Bazata of the Nebraska Department of Environmental Quality (formerly Nebraska Department of Environmental Control) for his insights regarding the State's stream-monitoring data that are discussed in this report.

\section{APPROACH}

On the scale of a NAWQA study area, commonly tens of thousands of square kilometers, only about 10 sites are intensively monitored. Therefore, data from more extensive monitoring programs conducted in the study area may provide opportunities to determine patterns and relations among environmental and biological components. During the mid- to late 1980's, the Nebraska Department of Environmental Control (NDEC) conducted a biological survey of 91 sites within the boundaries of the Central Nebraska Basins NAWQA study area (Nebraska Department of Environmental Control, 1991). Those data were used for the evaluation presented in this report.

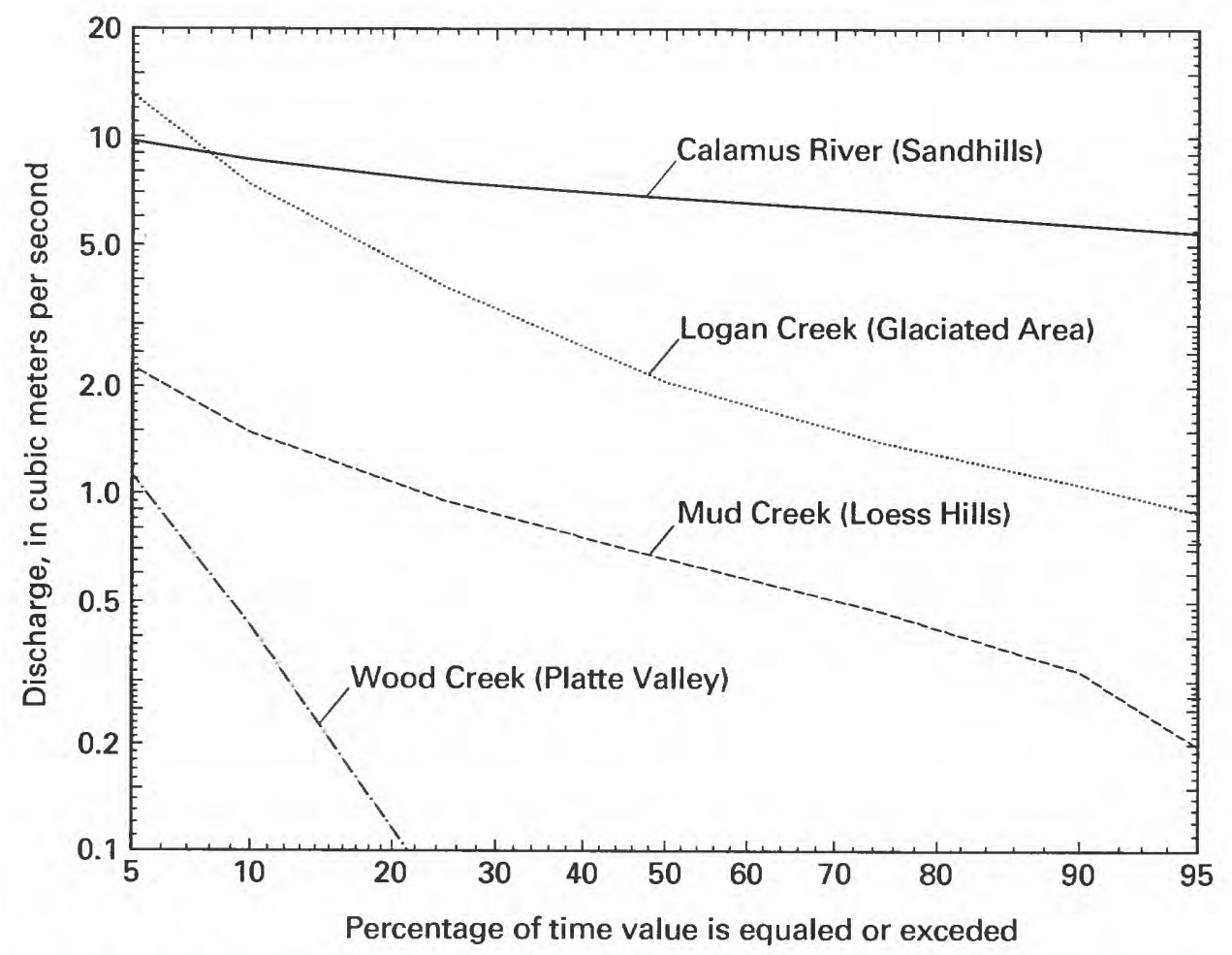

Figure 2. Flow-duration curves for streams of similar drainage areas in the four landscape subunits. 


\section{Cluster Analysis}

Crunkilton and Duchrow (1991) found that the use of multiple sites to define a reference condition improved the precision of bioassessments of macroinvertebrate communities in Missouri streams. NDEC did not use reference sites in their analysis of biotic integrity across the State (Nebraska Department of Environmental Control, 1991). Therefore, eight sites from the pool of potential references with spatial coverage across the study area were selected to create a synthetic reference condition. This synthetic reference condition comprised the median value for each RBP metric (table 1) except for the similarity metric. The similarity metric was excluded because a median cannot be derived from nonnumerical data such as a species list.

A cluster analysis of 91 sites on the basis of macroinvertebrate data was used to explore relations between community composition and a site's environmental setting and overall RBP scores. Gauch (1982) recommends TWINSPAN (Hill, 1979) for cluster analysis because it is an effective and robust way to summarize complex data. Using TWINSPAN, species abundance can be examined in many ways. Initial examination showed that the use of four abundance categories $(1-3,4-15,16-63$, more than 63 individuals per sample) was an effective way of treating both rare and abundant taxa. The data revealed that some- times abundant taxa were reported as more than 100 individuals per sample, whereas in other cases actual counts exceeding 100 per sample were reported. The second division of sites resulted in four clusters. This allowed clusters of sites to be tested for correspondence to the four landscape subunits contained within the study area by using a log-likelihood ratio test for contingency table data (Zar, 1984).

Each pair of clusters created by both the first and second divisions also was tested for differences in RBP scores, individual metrics that contribute to the RBP score, and subunit associations. Wilcoxon ranksum tests (as described by Helsel and Hirsch, 1992) were used to test whether RBP and individual metrics scores were different among clusters. Because the examination of metrics entails multiple comparisons, a Bonferroni correction was applied to maintain an overall $\alpha$ (the probability that a result occurs by chance) at 0.10 (Keppel, 1982). Therefore, the $\alpha$ for each of the eight individual comparisons was 0.0125 .

\section{Canonical Correspondence Analysis}

Environmental variables measured by NDEC at 57 of the 91 sites and examined in this analysis included site-specific measures of specific conductance, dissolved-oxygen concentration, stream width, mean depth, water temperature, substrate composition, and latitude (Nebraska Department of Environmental Con-

Table 1. Synthetic reference condition (median value for each metric from eight sites) used for RBP site assessment

[HBI, Hilsenhoff Biotic Index (Hilsenhoff, 1987); EPT, the orders Ephemeroptera, Plecoptera, and Trichoptera; Dominance, percentage of the sample composed of the most common taxon in the sample]

\begin{tabular}{lccccccc}
\hline \multicolumn{1}{c}{ Site name } & $\begin{array}{c}\text { Number } \\
\text { of taxa }\end{array}$ & HBI & $\begin{array}{c}\text { Scrapers- } \\
\text { to- } \\
\text { filterers } \\
\text { ratio }\end{array}$ & $\begin{array}{c}\text { EPT-to- } \\
\text { Chirono- } \\
\text { midae ratio }\end{array}$ & $\begin{array}{c}\text { Domi- } \\
\text { nance }\end{array}$ & $\begin{array}{c}\text { Number } \\
\text { of EPT } \\
\text { taxa }\end{array}$ & $\begin{array}{c}\text { Shredders- } \\
\text { to-total } \\
\text { individuals } \\
\text { ratio }\end{array}$ \\
\hline $\begin{array}{l}\text { South Branch Middle Loup } \\
\quad \text { River }\end{array}$ & 31 & 2.91 & 0.460 & 2.0 & 34.0 & 14 & 0.078 \\
$\begin{array}{l}\text { Goose Creek } \\
\text { Holt Creek }\end{array}$ & 35 & 2.36 & .958 & 1.6 & 22.6 & 14 & .173 \\
South Logan Creek & 36 & 3.73 & 1.139 & 1.13 & 23.4 & 9 & .082 \\
South Loup River & 31 & 3.44 & .755 & 1.0 & 17.8 & 11 & .091 \\
$\begin{array}{l}\text { Decker Creek } \\
\text { Union Creek }\end{array}$ & 22 & 3.26 & .136 & 2.0 & 29.3 & 12 & .061 \\
Clear Creek & 30 & 3.47 & .906 & .83 & 24.9 & 5 & .050 \\
$\begin{array}{l}\text { Synthetic reference } \\
\quad \text { condition }\end{array}$ & 27 & 3.38 & .241 & .82 & 13.5 & 9 & .124 \\
\hline
\end{tabular}


trol, 1991). Basin characteristics determined by the U.S. Geological Survey were drainage area; percentage of drainage in three land-use categories-rangeland, cropland and pasture, and wetlands (Anderson and others, 1976); ground-water nitrate concentration; stream-channel slope; mean annual precipitation; soil permeability; and maximum soil slope. Stream-channel slope was determined by measuring stream distance on topographic maps between the two contours crossing the stream upstream and downstream from each site. Data for all variables were examined graphically to check for normality. Stream width and substrate variables were transformed to approach a more normal distribution; other environmental variables had near-normal distributions and were not transformed.

Ground water contributes some part of streamflow throughout the year and is a major component of total streamflow during summer low flows. Because macroinvertebrate assemblages were sampled during low flows, ground-water quality may have affected assemblage composition. Nitrate concentration is the most common water-quality constituent measured in central Nebraska's ground water (Zelt and Jordan, 1993).

Median nitrate values from wells sampled from 1981-90 (number of wells varied by site drainage area) were used as a relative measure of nonpoint-source agricultural contamination of the ground water.

Soil permeability (average for upper 1.5 meters of soil) and (maximum) slope data were obtained from the State Soil Geographic Data Base (U.S. Department of Agriculture, 1991). Methods described by Dugan (1984) were used in conjunction with a geographic information system (GIS) to produce weighted average values for these soil characteristics in each basin. Stream channel slope, maximum soil slope, site altitude, and mean annual precipitation were obtained from GIS data compiled by the U.S. Geological Survey. Basinwide characteristics generally were determined from 1:250,000-scale data, whereas site altitude and channel slope were determined from 1:24,000-scale data.

The degree to which environmental variables are associated with taxa distribution and abundance was determined using canonical correspondence analysis (CCA) with the computer program CANOCO (Ter Braak, 1988). CCA is a multivariate technique developed to summarize relations among environmental factors and species distribution (Ter Braak and Prentice, 1988). Ordination diagrams produced by
CANOCO show community variation as constrained by environmental variation. Macroinvertebrate abundance data were not normally distributed and were transformed for these analyses. Rare species were retained during the CCA and were not downweighted. Forward selection was used to identify a small set of environmental variables that explained nearly as much of the variability in the species response to environmental conditions as did the complete set of environmental variables. A Monte Carlo test of 99 random permutations tested the significance of each environmental variable during the forward selection process (Ter Braak, 1988). Only variables determined to be significant (on the basis of $\alpha=0.05$ ) were included in the CCA.

Environmental variables determined to be significant were tested for strength and independence by performing a series of CCAs and partial CCAs. When CCA is performed on individual environmental variables, the first axis is constrained to that variable, and subsequent axes are unconstrained. Eigenvalues represent the relative strength of an environmental variable in explaining variability of species distribution in the ordination. Variables that explain more variation in the species data have the larger ratios of eigenvalues on the first axis to the second axis (Kingston and others, 1992). Independence of the significant variables was tested using partial CCA in which each individual variable was tested with the other variables included as covariables in the analysis. Results of the Monte Carlo permutation tests of individual variables included in the partial CCA with $p>0.05$ ( $p$ is the attained significance level) suggest nonindependence of the variables.

\section{RESULTS OF ANALYSES}

Four clusters produced by the classification of macroinvertebrate data from 91 sites showed some dependence on the landscape subunit in which a site was located. The hypothesis that composition of the four clusters was independent of the landscape subunits in which sites were located was rejected $(\mathrm{p}<0.001$ ) (table 2).

Cluster analysis showed significant differences at the first division of sites for the RBP scores and three individual metrics. Metrics that showed significant differences between those clusters were those that are affected by Ephemeroptera, Plecoptera, and Trichoptera (EPT). This first division may represent clus- 
Table 2. Contingency table for TWINSPAN clusters and log-likelihood ratio test statistic

[Log-likelihood ratio test statistic for contingency table data (Zar, 1984) $\mathrm{G}=57.1, \mathrm{p}<0.001$ ]

\begin{tabular}{lrrrrr}
\hline & \multicolumn{5}{c}{ Number of sites } \\
\cline { 2 - 6 } $\begin{array}{c}\text { Subunit } \\
\text { (fig. 1) }\end{array}$ & $\begin{array}{c}\text { Clus- } \\
\text { ter } \\
\mathbf{0 0}\end{array}$ & $\begin{array}{c}\text { Clus- } \\
\text { ter } \\
\mathbf{0 1}\end{array}$ & $\begin{array}{c}\text { Clus- } \\
\text { ter } \\
\mathbf{1 0}\end{array}$ & $\begin{array}{c}\text { Clus- } \\
\text { ter 11 }\end{array}$ & Total \\
\hline Sandhills & 15 & 4 & 4 & 0 & 23 \\
Loess Hills & 12 & 7 & 2 & 1 & 22 \\
Glaciated Area & 0 & 15 & 2 & 13 & 30 \\
Platte Valley & 6 & 2 & 4 & 4 & 16 \\
$\quad$ Total & $\mathbf{3 3}$ & $\mathbf{2 8}$ & $\mathbf{1 2}$ & $\mathbf{1 8}$ & $\mathbf{9 1}$ \\
\hline
\end{tabular}

ters of sites with higher RBP scores (cluster 0, median score 76) and lower RBP scores (cluster 1, median score 62) (table 3). Hilsenhoff's Biotic Index (HBI) (Hilsenhoff, 1987), the EPT-to-Chironomidae ratio, and the number of EPT taxa each were significantly different between the first two clusters of sites. The EPT-to-Chironomidae ratio and the HBI also were different between clusters 00 and 01 (created by the division of cluster 0 ). Metrics describing the number of taxa, ratio of scrapers to filterers, dominance, and the ratio of shredders to total individuals failed to show significant differences between clusters of sites at any level of classification.

CCA showed that the cumulative effect of environmental variables was strongly correlated with patterns of macroinvertebrate distribution (correlation coefficient, $r,>0.90$ for ordination axes 1 and 2). Ordination axis 1 was best correlated with stream width $(r=0.45)$, and axis 2 was best correlated with soil permeability $(r=0.36)$ and site altitude $(r=0.34)$. Stream width was the most important variable (eigenvalue 0.25 ) followed by site altitude, latitude, soil permeability, water temperature, and mean annual precipitation (table 4, fig. 3). Nearly all variables affected species independently; the effect of precipitation was not independent of soil permeability $(p=0.06$, table 5$)$.

\section{EVALUATION OF CENTRAL NEBRASKA STREAMS}

Water-quality impairment has broad meaning, including chemical alteration from natural conditions and habitat modification (Rosenberg and others, 1986;
Courtemanch and others, 1989). Because natural conditions are varied, deviations from expected conditions based on multiple reference sites suggest impairment to water quality (Plafkin and others, 1989). However, because sites were scored relative to a synthetic reference, small deviations from this median condition would not be considered an impairment.

\section{Cluster Analysis}

Macroinvertebrate assemblages were not randomly distributed across four landscape subunits in central Nebraska (table 2). At least some of these clusters of sites presumably represent areas of different environmental conditions or human effects. The significant difference in RBP scores between sites forming the clusters 0 and 1 in table 3 implies that water quality (including chemical composition and habitat condition) differed between those groups of sites. Individual metrics that also differed between groups of sites may provide insight to the nature of impairments.

The HBI (Hilsenhoff, 1987) uses each taxon's pollution tolerance and its relative abundance to evaluate an assemblage's tolerance to organic pollution. Barbour and others (1992) reexamined the metrics that comprise the U.S. Environmental Protection Agency's RBP metrics (Plafkin and others, 1989) and determined that the HBI was one of the metrics whose variability was small enough to distinguish between montane and plains reference sites. A modification of the HBI, the Family HBI (Hilsenhoff, 1988), also was found to be effective in discriminating affected and unaffected sites (Resh and Jackson, 1993). The HBI was significantly different at the first division of sites in central Nebraska (table 3), suggesting a distinction between affected and unaffected sites.

Sensitivity to a broad range of pollutants and habitat degradation characterizes the EPT taxa. The number of EPT taxa was significantly different between sites in clusters 0 and 1 , again suggesting a distinction between affected and unaffected sites. Although Barbour and others (1992) found taxa richness (the total number of taxa in a sample) to be a better metric for discriminating ecoregional differences than the EPT metric, the same result was not observed in central Nebraska. Overall taxa richness was not significantly different ( $\mathrm{p}=0.4294$, table 3 ) between clusters 0 and 1 , yet the EPT taxa difference was highly significant $(p<0.0001)$. A possible explanation of the disparity 
Table 3. Results of Wilcoxon rank-sum tests between clusters of stream sites in central Nebraska

[Significant differences of $\mathrm{p}<0.0125$ in bold type; RBP, rapid bioassessment protocol for macroinvertebrates (Plafkin and others, 1989); HBI. Hilsenhoff Biotic Index (Hilsenhoff, 1987); EPT, the orders Ephemeroptera, Plecoptera, and Trichoptera; Dominance, percentage of the sample composed of the most common taxon in the sample; $n$, number of sites]

\begin{tabular}{|c|c|c|c|c|c|c|c|c|}
\hline \multirow[b]{2}{*}{$\begin{array}{l}\text { Clusters } \\
\text { compared }\end{array}$} & \multicolumn{8}{|c|}{ p-value } \\
\hline & RBP & $\begin{array}{c}\text { Number } \\
\text { of taxa }\end{array}$ & HBI & $\begin{array}{l}\text { Scrapers-to- } \\
\text { filterers ratio }\end{array}$ & $\begin{array}{l}\text { EPT-to- } \\
\text { Chirono- } \\
\text { midae } \\
\text { ratio }\end{array}$ & Dominance & $\begin{array}{c}\text { Number } \\
\text { of EPT } \\
\text { taxa }\end{array}$ & $\begin{array}{c}\text { Shredders-to- } \\
\text { total } \\
\text { individuals } \\
\text { ratio }\end{array}$ \\
\hline $\begin{array}{l}0 \text { and } 1 \\
(n=61)(n=30)\end{array}$ & 0.0005 & 0.4294 & $<0.0001$ & 0.2146 & 0.0111 & 0.8427 & $<0.0001$ & 0.0154 \\
\hline $\begin{array}{l}00 \text { and } 01 \\
(n=33)(n=28)\end{array}$ & .5208 & .0463 & .0001 & .3322 & $<.0001$ & .0328 & .1977 & .5148 \\
\hline $\begin{array}{l}10 \text { and } 11 \\
(n=12)(n=18)\end{array}$ & .4684 & .6714 & .6719 & .0140 & .0131 & .4335 & .6078 & .9662 \\
\hline
\end{tabular}

Table 4. Ranking of environmental variables from forward selection in canonical correspondence analysis

\begin{tabular}{lcc}
\hline \multicolumn{1}{c}{ Variable $^{1}$} & Eigenvalue & p-value \\
\hline Stream width & 0.25 & 0.01 \\
Site altitude & .24 & .01 \\
Latitude & .17 & .01 \\
Soil permeability & .14 & .01 \\
Water temperature & .12 & .01 \\
Mean annual precipitation & .10 & .01 \\
\hline
\end{tabular}

'All other variables were not significant $(\alpha=0.05)$.

between studies is that Barbour and others (1992) compared unaffected streams in montane and plains settings, whereas only plains streams with unknown degrees of impairment were examined in central Nebraska.

The EPT-to-Chironomidae ratio was significantly different between clusters of sites in two of three comparisons. Neither Barbour and others (1992) nor Resh and Jackson (1993) found this metric to consistently discriminate among groups of sites. This metric is meant to measure the balance of pollution-sensitive and pollution-tolerant organisms. Chironomidae are abundant organisms in the sand-bottom streams of the plains (Ferrington, 1987) and were well represented in the NDEC samples. In central Nebraska, sites with lower scores for this metric probably reflect a loss of EPT taxa. Although the EPT taxa metric measures numbers of taxa and the EPT-to-Chironomidae ratio measures numbers of individuals, there is some redundancy between these metrics.
In Nebraska streams, the natural harshness of an unstable sand streambed may obviate functional feeding group (for example, grazers and shredders) and dominance metrics. Periphyton growth, and thus grazers, may be limited to slack-water areas where bed material is stable during low flow. Shredder abundance likely is limited by relatively open canopies associated with the upstream reaches of prairie streams or very wide braided channels. Decreased taxa richness and an increased percentage of the dominant taxa generally are considered an indication of impaired water quality. Although human alteration can create harsh environments, if the reference condition is naturally harsh, then these metrics will be ineffective in evaluating water-quality impairment.

Although TWINSPAN was useful for determining sites with similar macroinvertebrate assemblages and possible water-quality impairment, the cluster analysis did not identify factors that may contribute to assemblage structure. Typically, RBPs are used for monitoring by detecting areas with anomalous assemblage structure, and sites where conditions deviate from expectations are investigated in more detail to identify factors potentially responsible for the observed condition. This process may entail the use of a direct gradient analysis such as CCA.

\section{Canonical Correspondence Analysis}

Macroinvertebrate assemblages may not respond directly to any variables included in an ordination but rather to some unmeasured characteristic strongly cor- 


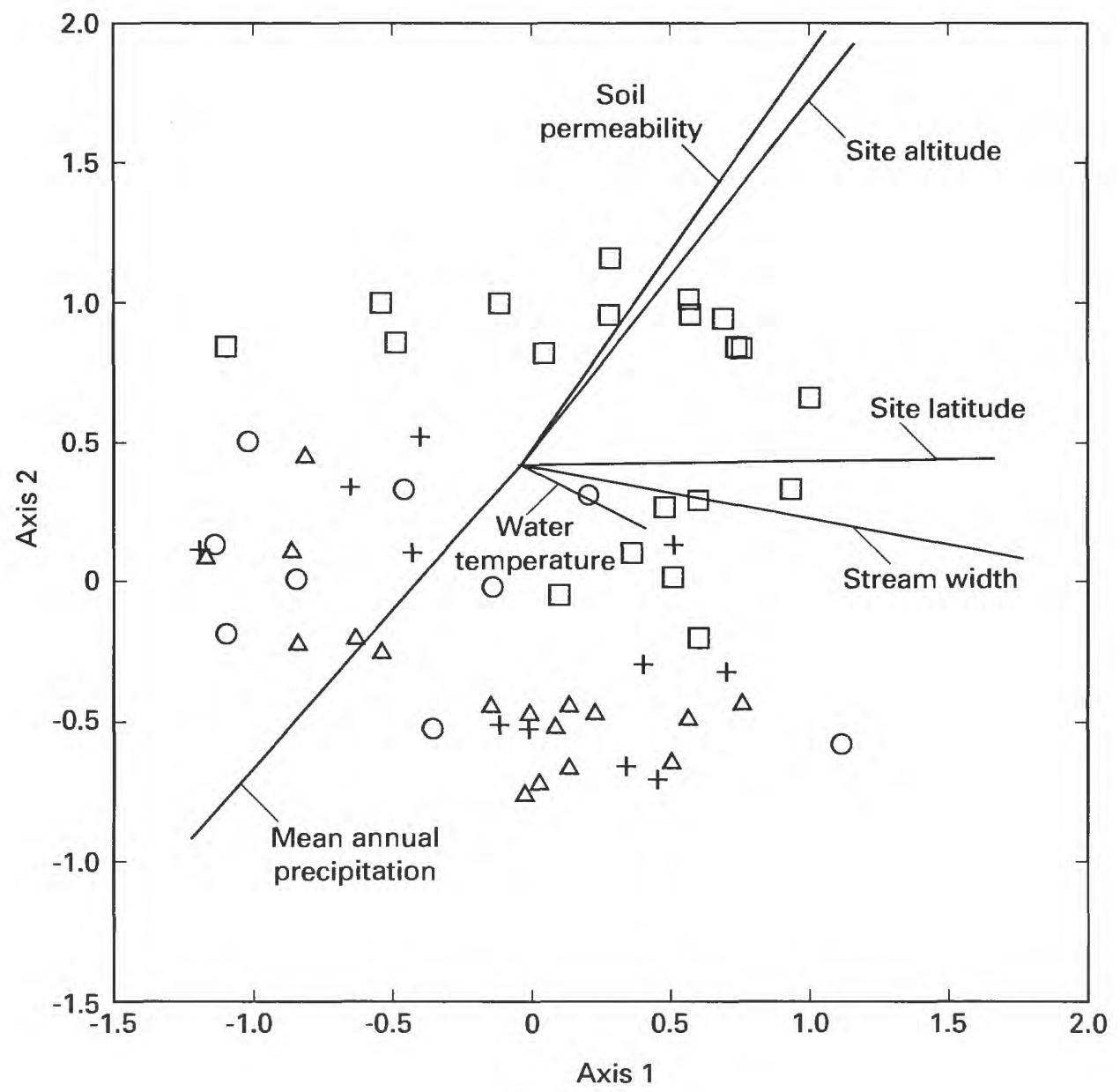

EXPLANATION

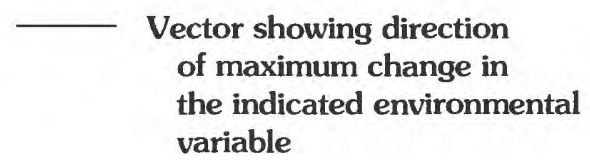
Sampling site
Sandhills
+ Loess Hills
$\Delta$ Glaciated Area
O Platte Valley

Figure 3. Ordination of site locations on the basis of macroinvertebrate community composition and environmental variables.

related with variables in the ordination (Wright and others, 1984). This study appears to reiterate the importance of stream width, or a correlated variable, to macroinvertebrate assemblage composition (see Corkum and Currie, 1987; Corkum 1990; Malmqvist and Maki, 1994). Malmquist and Maki (1994) noted that larger streams offer more possible areas of refuge for survival and dispersal thereby producing greater species richness. Discharge, food availability, and habitat diversity are variables that may correlate (either positively or negatively) with stream width in
Nebraska. Inevitably, streams widen to accommodate discharge gained in a downstream direction. The structure of macroinvertebrate assemblages is hypothesized to respond to changes in food sources via the relative contribution of riparian litter to the stream (Vannote and others, 1980). Although small headwater streams commonly are most strongly affected by riparian inputs (that is, a negative correlation with stream width), prairie streams may exhibit the opposite relation with riparian vegetation absent from upstream reaches (Wiley and others, 1990). For streams in the 
Table 5. Results of $(A)$ canonical correspondence analysis and $(B)$ partial canonical correspondence analysis of significant environmental variables

$\left[\lambda_{1}\right.$, eigenvalue for the first constrained axis; $\lambda_{2}$, eigenvalue for the first unconstrained axis]

A. Canonical correspondence analysis

\begin{tabular}{lrrr}
\hline \multicolumn{1}{c}{ Variable } & $\lambda_{1}$ & $\lambda_{2}$ & $\lambda_{1} / \lambda_{2}$ \\
\hline Stream width & 0.253 & 0.311 & 0.81 \\
Site altitude & .252 & .398 & .63 \\
Soil permeability & .245 & .400 & .61 \\
Latitude & .231 & .318 & .73 \\
Water temperature & .120 & .401 & .30 \\
Mean annual & .230 & .394 & .58 \\
$\quad$ precipitation & & & \\
\hline
\end{tabular}

B. Partial canonical correspondence analysis

\begin{tabular}{|c|c|c|}
\hline Variable & Covariable & p-value \\
\hline \multirow[t]{5}{*}{ Stream width } & Site altitude & 0.01 \\
\hline & Soil permeability & .01 \\
\hline & Latitude & .01 \\
\hline & Water temperature & .01 \\
\hline & $\begin{array}{l}\text { Mean annual } \\
\text { precipitation }\end{array}$ & .01 \\
\hline \multirow[t]{5}{*}{ Site altitude } & Soil permeability & .02 \\
\hline & Latitude & .01 \\
\hline & Water temperature & .01 \\
\hline & $\begin{array}{l}\text { Mean annual } \\
\text { precipitation }\end{array}$ & .01 \\
\hline & Stream width & .01 \\
\hline \multirow[t]{5}{*}{ Soil permeability } & Latitude & .01 \\
\hline & Water temperature & .01 \\
\hline & $\begin{array}{l}\text { Mean annual } \\
\text { precipitation }\end{array}$ & .03 \\
\hline & Stream width & .01 \\
\hline & Site altitude & .02 \\
\hline \multirow[t]{5}{*}{ Latitude } & Water temperature & .01 \\
\hline & $\begin{array}{l}\text { Mean annual } \\
\text { precipitation }\end{array}$ & .01 \\
\hline & Stream width & .01 \\
\hline & Site altitude & .01 \\
\hline & Soil permeability & .01 \\
\hline \multirow[t]{5}{*}{ Water temperature } & $\begin{array}{l}\text { Mean annual } \\
\text { precipitation }\end{array}$ & .02 \\
\hline & Stream width & .04 \\
\hline & Site altitude & .02 \\
\hline & Soil permeability & .02 \\
\hline & Latitude & .03 \\
\hline \multirow[t]{5}{*}{$\begin{array}{c}\text { Mean annual pre- } \\
\text { cipitation }\end{array}$} & Stream width & .01 \\
\hline & Site altitude & .02 \\
\hline & Soil permeability & .06 \\
\hline & Latitude & .01 \\
\hline & Water temperature & .01 \\
\hline
\end{tabular}

study area, the measured variable of stream width may be a surrogate for the unmeasured effect of riparian vegetation on macroinvertebrate assemblages.

Macroinvertebrate assemblages in Nebraska may reflect different streamflow regimes, an interpretation supported by the significance of soil permeability in the CCA. Streamflow was identified as an important integrator of complex environmental conditions by Statzner and Hilger (1986), Resh and others (1988), and Poff and Ward (1989). The more hydrologically stable Sandhills sites were separated in the ordination from other sites along gradients of soil permeability, site altitude, and precipitation.

Corkum (1989) noted that altitude and latitude accounted for significant variability in the distribution of macroinvertebrates in northwestern North America. CCA showed that factors associated with climate (site altitude and latitude) were significant to macroinvertebrate distribution in Nebraska. In central Nebraska, site altitude roughly corresponds to longitude in that higher altitude sites are located in the western part of the study area. However, precipitation in the study area shows an increasing trend from west to east. Stream width and soil permeability are factors related to streamflow, whereas site altitude and latitude are factors related to climate. Mean annual precipitation is related to both streamflow and climate. The importance of climatic factors is in agreement with Cushing and others (1980) who observed that climatic variables of solar radiation and precipitation were strongly correlated with patterns of sites grouped by their macroinvertebrate assemblages.

Several studies have attributed spatial patterns of macroinvertebrate assemblages to land-use patterns. In the plains region of the South Platte River Basin, the difference between urban and mixed urban/agricultural land use was found to affect macroinvertebrate distribution (Tate and Heiny, 1995). Corkum (1990) found that land use (that is, agricultural versus forested) overrode the effect of natural vegetation patterns on macroinvertebrate assemblage composition. In central Nebraska, although land-use variables were included in the analysis, they were not significant in the CCA because most of the variability in macroinvertebrate assemblages that may be attributed to land use was accounted for by the variables strongly correlated with land use (soil permeability, precipitation, and latitude). It is the combination of physiographic and climatic factors that determine whether an area is suitable for crop production in Nebraska. For that rea- 
son, land-use variables proved to be redundant in the CCA.

Water temperature was a significant environmental variable as determined by the CCA. Wiley and others (1990) related water temperature to the longitudinal position of a site in a watershed and, therefore, to riparian canopy extent. More open upstream reaches showed higher daytime temperatures and also greater primary productivity. As with stream width, the inference is made that the significance of water temperature may be its association with unmeasured variables such as riparian vegetation.

\section{SUMMARY}

Ninety-one stream sites in central Nebraska were classified into four clusters on the basis of a cluster analysis (TWINSPAN) of macroinvertebrate data. Although the composition of the four clusters was not independent of the subunits in which sites were located, some of the clusters may have represented areas of different environmental conditions or human effects. Rapid bioassessment protocol scores for macroinvertebrate species were significantly different between sites grouped by the first division into two clusters. This division may have distinguished sites on the basis of water-quality impairment. Individual metrics that differed between clusters of sites were the Hilsenhoff Biotic Index, the number of Ephemeroptera, Plecoptera, and Trichoptera (EPT) taxa, and the ratio of individuals in EPT-to-Chironomidae taxa. Metrics for number of taxa, ratio of scrapers to filterers, percentage contribution of the dominant taxon, and ratio of shredders to total individuals were not significantly different between any two clusters of sites created by the division of a larger cluster. Although clusters of sites with water quality or habitat degradation were identified by site classification, the potential factors affecting the communities were not determined. However, the combination of a multimetric approach with a multivariate statistical approach produced complementary information. Canonical correspondence analysis of 57 of the 91 sites showed that stream width, site altitude, latitude, soil permeability, water temperature, and mean annual precipitation were the most important environmental variables describing variance in the species-environment relation. Stream width and soil permeability reflected streamflow characteristics of a site, whereas site altitude and latitude were factors related to general climatic conditions. Mean annual precipitation related both to streamflow and climatic conditions.

\section{REFERENCES}

Anderson, J.R., Hardy, E.E., Roach, J.T., and Witmer, R.E., 1976, A land use and land cover classification system for use with remote sensor data: U.S. Geological Survey Professional Paper 964, 28 p.

Barbour, M.T., Plafkin, J.L., Bradley, B.P., Graves, C.G., and Wisseman, R.W., 1992, Evaluation of EPA's rapid bioassessment benthic metrics-metric redundancy and variability among reference stream sites: Environmental Toxicology and Chemistry, v. 11, p. 437-449.

Corkum, L.D., 1989, Patterns of benthic invertebrate assemblages in rivers of northwestern North America: Freshwater Biology, v. 21, p. 191-205.

-1990 , Intrabiome distributional patterns of lotic macroinvertebrate assemblages: Canadian Journal of Fisheries and Aquatic Sciences, v. 47, p. 2147-2157.

Corkum, L.D., and Currie, D.C., 1987, Distributional patterns of immature Simuliidae (Diptera) in northwestern North America: Freshwater Biology, v. 17, p. 201-221.

Courtemanch, D.L., Davies, S.P., and Laverty, E.B., 1989 , Incorporation of biological information in water quality planning: Environmental Management, v. 13, p. 35-41.

Crunkilton, R.L., and Duchrow, R.M., 1991, Use of stream order and biological indices to assess water quality in the Osage and Black River Basins of Missouri: Hydrobiologia, v. 224, p. 155-166.

Cushing, C.E., McIntire, C.D., Sedell, J.R., Cummins, K.W., Minshall, G.W., Petersen, R.C., and Vannote, R.L., 1980, Comparative study of physical-chemical variables of streams using multivariate analyses: Archiv fur Hydrobiologie, v. 89, p. 343-352.

Dixit, S.S., Smol, J.P., Kingston, J.C., and Charles, D.F., 1992, Diatoms-Powerful indicators of environmental change: Environmental Science \& Technology, v. 26, p. 22-33.

Dugan, J.T., 1984, Hydrologic characteristics of Nebraska soils: U.S. Geological Survey Water-Supply Paper 2222, 19 p., 12 plates.

Ferrington, L.C., Jr., 1987, Chironomidae in the capillary fringe of the Cimarron River bed: Journal of the Kansas Entomological Society, v. 60, no. 1, p. 153-156.

Gauch, H.G., Jr., 1982, Multivariate analysis in community ecology: Cambridge, Cambridge University Press, 298 p.

Hill, M.O., 1979, TWINSPAN-A FORTRAN program for arranging multivariate data in an ordered two-way table by classification of the individuals and attributes: Ithaca, N.Y., Cornell University, unpaginated. 
Helsel, D.R., and Hirsch, R.M., 1992, Statistical methods in water resources: Amsterdam, Elsevier Science Publ., B. V., 522 p.

Hilsenhoff, W.L., 1987, An improved biotic index of organic stream pollution: Great Lakes Entomologist, v. 20 , p. $31-39$.

-1988, Rapid field assessment of organic pollution with a family-level biotic index: Journal of the North American Benthological Society, v. 7, p. 65-68.

Huntzinger, T.L., and Ellis, M.J., 1993, Central Nebraska river basins, Nebraska: Water Resources Bulletin, v. 29 , p. 533-574.

Karr, J.R., 1981, Assessment of biotic integrity using fish communities: Fisheries, v. 6, p. 21-27.

Karr, J.R., Fausch, K.D., Angermier, P.L., Yant, P.R., and Schlosser, I.J., 1986, Assessing biological integrity in running waters - a method and its rationale: Illinois Natural History Survey Special Publ., v. 5, 28 p.

Keppel, Geoffrey, 1982, Design \& analysis - a researcher's handbook (2nd ed): Englewood Cliffs, New Jersey, Prentice-Hall, Inc., 669 p.

Kingston, J.C., Birks, H.J.B., Uutala, A.J., Cumming, B.F., and Smol, J.P., 1992, Assessing trends in fishery resources and lake water aluminum from paleolimnological analyses of siliceous algae: Canadian Journal of Fisheries and Aquatic Sciences, v. 49, p. 116-127.

Leland, H.V., and Carter, J.L., 1986, Use of detrended correspondence analysis in evaluating factors controlling species composition of periphyton: American Society for Testing and Materials Special Technical Publication 894, p. 101-117.

Malmqvist, B., and Maki, M., 1994, Benthic macroinvertebrate assemblages in north Swedish streams-environmental relationships: Ecography, v. 17, p. 9-16.

Nebraska Department of Environmental Control, 1991, Nebraska stream classification study: Lincoln, Nebraska, Surface Water Section, Water Quality Division, 342 p.

Norris, R.H., 1995, Biological monitoring - the dilemma of data analysis: Journal of the North American Benthological Society, v. 14, p. $440-450$.

Norris, R.H., and Georges, A., 1993, Analysis and interpretation of benthic surveys, in Rosenberg, D.M., and Resh, V.H, eds., Freshwater biomonitoring and benthic macroinvertebrates: New York, Chapman and Hall, p. 234-286.

Omernik, J.M., 1987, Ecoregions of the conterminous United States: Annals of the Association of American Geographers, v. 77, p. 118-125.

Plafkin, J.L., Barbour, M.T., Porter, K.D., Gross, S. K., and Hughes, R.M., 1989, Rapid bioassessment protocols for use in streams and rivers - benthic macroinvertebrates and fish: U.S. Environmental Protection Agency, EPA/444/4-89-001, unpaginated.
Poff, N.L., and Ward. J.V.. 1989. Implications of streamflow variability and predictability for lotic community structure-a regional analysis of streamflow patterns: Canadian Journal of Fisheries and Aquatic Sciences, v. 46 , p. $1805-1818$.

Resh, V.H., Brown, A.V., Covich, A.P.. Gurtz. M.E., Li, H.W., Minshall, G.W., Reice, S.R., Sheldon, A.L., Wallace, J.B., and Wissmar, R.C., 1988, The role of disturbance in stream ecology: Journal of the North American Benthological Society, v. 7, p. 433-455.

Resh, V.H., and Jackson, J.K., 1993, Rapid assessment approaches to biomonitoring using benthic macroinvertebrates, in Rosenberg, D.M., and Resh, V.H, eds., Freshwater biomonitoring and benthic macroinvertebrates: New York, Chapman and Hall, p. 195-233.

Richards, Carl, Host, G.E., and Arthur, J.W., 1993, Identification of predominant environmental factors structuring stream macroinvertebrate communities within a large agricultural catchment: Freshwater Biology, v. 29 , p. $285-294$.

Rosenberg, D.M., Danks, H.V., and Lehmkuhl, D.M., 1986, Importance of insects in environmental impact assessment: Environmental Management, v. 10, p. 773-783.

Rosenberg, D.M., and Resh, V.H., 1993, Introduction to freshwater biomonitoring and benthic macroinvertebrates, in Rosenberg, D.M., and Resh, V.H., eds., Freshwater biomonitoring and benthic macroinvertebrates: New York, Chapman and Hall, p. 1-9.

Southerland, M.T., and Stribling, J.B., 1995, Status of biological criteria development and implementation, in Davis, W.S., and Simon, T.P., eds., Biological assessment and criteria-tools for water resource planning and decision-making: Chelsea, Michigan, Lewis Publishers, p. 81-96.

Statzner, B., and Hilger, B., 1986, Stream hydraulics as a major determinant of benthic invertebrate zonation patterns: Freshwater Biology, v. 16, p. 127-139.

Tate, C.M., and Heiny, J.S., 1995, The ordination of benthic invertebrate communities in the South Platte River Basin in relation to environmental factors: Freshwater Biology, v. 33, p. 439-454.

Ter Braak, C.J.F., 1988, CANOCO-A FORTRAN program for canonical community ordination by [partial] [detrended] [canonical] correspondence analysis, principal components analysis and redundancy analysis (version 2.1): The Netherlands, Agricultural Mathematics Group Technical Report LWA-88-02, 95 p.

Ter Braak, C.J.F., and Prentice, I.C., 1988, A theory of gradient analysis: Advances in Ecological Research, v. 18, p. 272-313.

U.S. Department of Agriculture, 1991, State soil geographic data base (STATSGO) data users guide: Soil Conservation Service Miscellaneous Publication Number 1492, $88 \mathrm{p}$. 
Vannote, R.L, Minshall, G.W., Cummins, K.W., Sedell, J.R., and Cushing, C.E., 1980, The river continuum concept: Canadian Journal of Fisheries and Aquatic Sciences, v. 37, p. 130-137.

Wiley, M.J., Osborne, L.L., and Larimore, R.W.. 1990, Longitudinal structure of an agricultural prairie river system and its relationship to current stream ecosystem theory: Canadian Journal of Fisheries and Aquatic Sciences, v. 47 , p. 373-384.
Wright, J.F., Moss, D., Armitage, P.D., and Furse, M.T., 1984, A preliminary classification of running-water sites in Great Britain based on macro-invertebrate species and the prediction of community type using environmental data: Freshwater Biology, v. 14, p. 221-256.

Zar, J.H., 1984, Biostatistical analysis: Englewood Cliffs, New Jersey, Prentice-Hall, Inc., 718 p.

Zelt, R.B., and Jordan, P.R., 1993, Water-quality assessment of the Central Nebraska Basins-Summary of data for recent conditions through 1990: U.S. Geological Survey Open-File Report 93-422, 179 p. 